Journal of Advanced Research in Fluid Mechanics and Thermal Sciences

Journal homepage: www.akademiabaru.com/arfmts.html ISSN: $2289-7879$

\title{
3D Printing Technology for Thermal Application: A Brief Review
}

\author{
Rajan Kumaresan ${ }^{1}$, Mahendran Samykano ${ }^{2,}{ }^{,}$, Kumaran Kadirgama ${ }^{1}$, Devarajan Ramasamy ${ }^{2}$, Ngui \\ Wai Keng ${ }^{2}$, Adarsh Kumar Pandey ${ }^{3}$ \\ Faculty of Mechanical \& Automotive Engineering Technology, Universiti Malaysia Pahang, 26600 Pekan, Pahang, Malaysia \\ 2 College of Engineering, Universiti Malaysia Pahang, 26300 Gambang, Pahang, Malaysia \\ 3 Research Centre for Nano-Materials and Energy Technology (RCNMET), School of Science and Technology, Sunway University, No. 5, Jalan \\ Universiti, Bandar Sunway, Petaling Jaya, 47500 Selangor Darul Ehsan, Malaysia
}

\section{ARTICLE INFO}

\section{Article history:}

Received 31 December 2020 Received in revised form 29 April 2021 Accepted 5 May 2021 Available online 16 June 2021

\section{Keywords:}

Additive Manufacturing; 3D printing; Thermal; Energy; Impact Energy

\section{ABSTRACT}

\begin{abstract}
3D printing is an emerging technology to construct complex geometry by adapting layer-by-layer addition technique from a 3-dimensional CAD model. Mass customization, freedom of design, and wastage minimization are the main advantages of Additive Manufacturing (AM) based 3D printing. 3D printing is currently used in many sectors worldwide, such as automotive, aerospace, agriculture, medical, electronics, and other household products. However, the usage of the AM technique is limited in large production sectors due to the limitation of the materials and properties of the produced parts. In this review, the different methods of 3D printing, the materials used in different processes, various fields of applications, and the properties of the different approaches are discussed. Also, the effect of process parameters such as layer thickness, nozzle temperature, platform temperature, printing speed, extruding rate, and layer height in 3d printing was reviewed. This will be helpful for further development of 3D printed product quality and applications in various sectors.
\end{abstract}

\section{Introduction}

3D printing, one of the methods in Additive Manufacturing (AM), is a process of constructing materials with complex geometry using a layer-by-layer technique from 3-dimensional CAD data [1]. In 1986, Charles Hull developed the initial AM process named stereolithography (SLA) and further enhanced it to various other technologies such as powder bed fusion (PBF), fused deposition modeling (FDM), and contour crafting (CC). The increasing demands for the cost-efficient project, lightweight products, and polymer-based composites materials upsurge the use, research, and technology development of 3D printing. These days, 3D printing is used in many sectors like aerospace, medical, electronics, construction, and other housed hold products [1]. 3D printing is a truly revolutionary technology that has evolved as a multifaceted process step. It opens new possibilities for businesses trying to maximize production productivity and offers hope for many

\footnotetext{
* Corresponding author.

E-mail address: mahendran@ump.edu.my
}

https://doi.org/10.37934/arfmts.83.2.8497 
opportunities. Materials such as polymers, polymer composites, ceramics, metals, and nanomaterials are used in the AM process. The 3D printing technology is extensively used for the development of customized complex geometries for the automotive, aerospace, agriculture, and healthcare sectors [2].

Conversely, the use of 3D printing technology in the industry has several drawbacks. The application over many sectors has been restricted because of the availability of limited materials. Another primary reason is product quality, cost-effectiveness, and mass production capability [3]. The 3D printing technique is not suitable for mass production compared to the conventional process as they are more time-consuming and high cost. Apart from that, the product's mechanical properties are also affected by the processing technique, processing parameters, and limited material availability.

Thus, the present review is focused on reviewing and providing insights related to the various process of 3D printing, materials used in the 3D printing process and the properties and the various applications of the 3D printing, and the effect of the process parameters in the AM process.

\section{Types of 3D Printing Process}

American Society of Standards classified the AM into seven categories, Material Extrusion (ME), Powder Bed Fusion (PBF), Binder Jetting (BJ), Material Jetting (MJ), Sheet Lamination (SL), Vat Photopolymerization (VP), and Direct Energy Deposition (DED) [3]. No debate exists about which machine or technology works best because each one has its specific applications and advantages. At present, 3D printing methods are no longer limited to prototyping but are rapidly being used to produce a wide range of products [4]. The various categories of the AM process are discussed below.

(i) Materials Extrusion (ME)

Materials Extrusion (ME) is an AM technique in which the material is heated and selectively dispensed to form a 3D component through a nozzle. Fused Deposition Modeling (FDM) or Fused Filament Fabrication (FFF) is one of the imperative machining processes of this category. The material extrusion process can be used to print plastics, foods, and living cells in multi-color or multi-materials. This method is widely used to build up fully functional parts cheaper and quicker [5]. The first example of the material extrusion process is FDM, which was developed in 1989. Polymers are used as the primary material in this process [6]. Figure 1 indicates the schematic diagram of the material extrusion FDM process. 


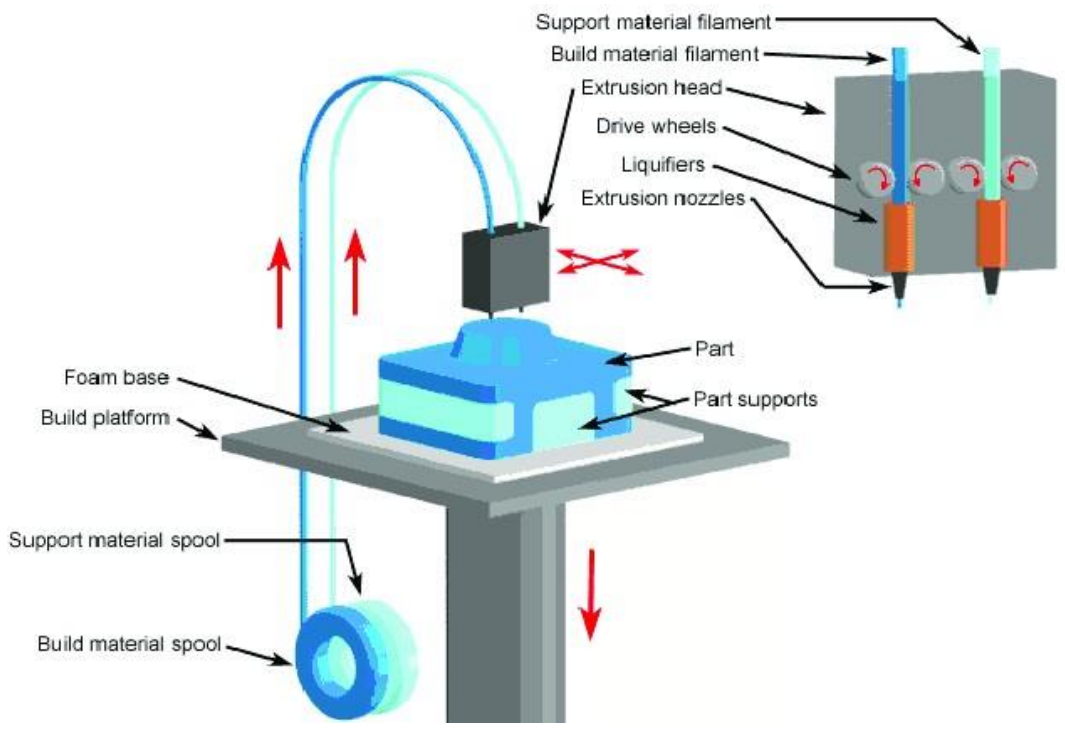

Fig. 1. Schematic representation of the FDM printer [2]

(ii) Powder Bed Fusion (PBF)

Powder Bed Fusion (PBF) is operated by deliberately melting the powder using either an electron beam, laser, or other heating elements. Selective Laser Sintering (SLS), Electron Beam Melting (EBM), and Selective Heat Sintering (SHS) are examples of printing techniques in this process [8]. Polymers, metals, ceramics, composites, and hybrid materials can be prepared using this process. SLS is the prominent printing techniques of this process. The SLS printing technology is developed in 1987 by Carl Deckard. The product in this technique is produced by sintering the powders using a high-power laser. The key advantage of this process is the machine speed, accuracy, and good surface finish [9]. Figure 2 represents the working of the SLS technique.

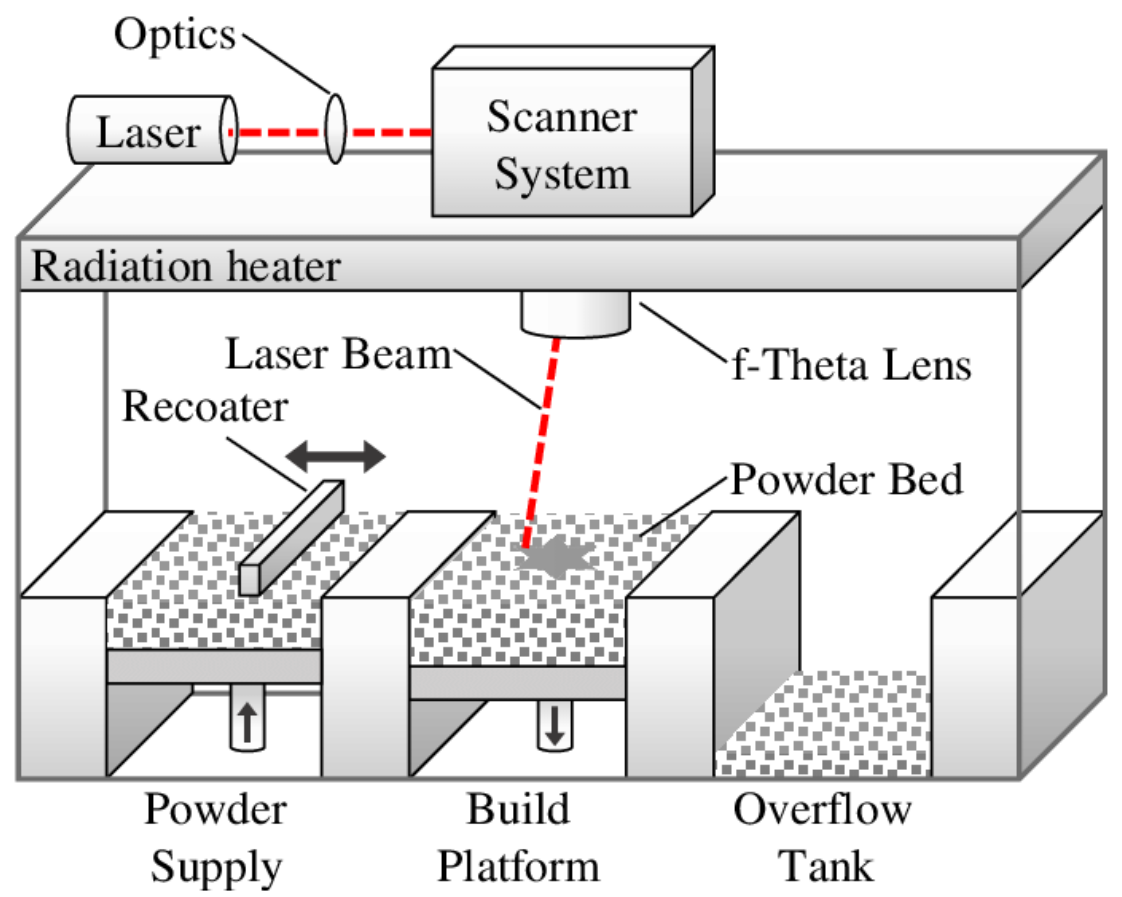

Fig. 2. Schematic diagram of Selective Laser Sintering [3] 


\section{(iii) Binder Jetting (BJ)}

Binder Jetting (BJ) is an AM technique that distributes powdered material into a layer and selectively joins them using a binder into the desired layer form, usually, they are in the form of polymer liquid. In this process, the layer is formed using a jet chemical binder [2]. A roller is used to spread the powder from the powder supply platform to the fabrication platform, and a recoater is used to spread powder from a top hopper by vibration. Binder jetting can print materials such as polymers, metals, ceramics, sands, and hybrids. 3D printing and inkjet printing are important techniques of this process. The process is simple, fast, cheaper, and able to print using large particles. Figure 3 shows the working of the BJ process.

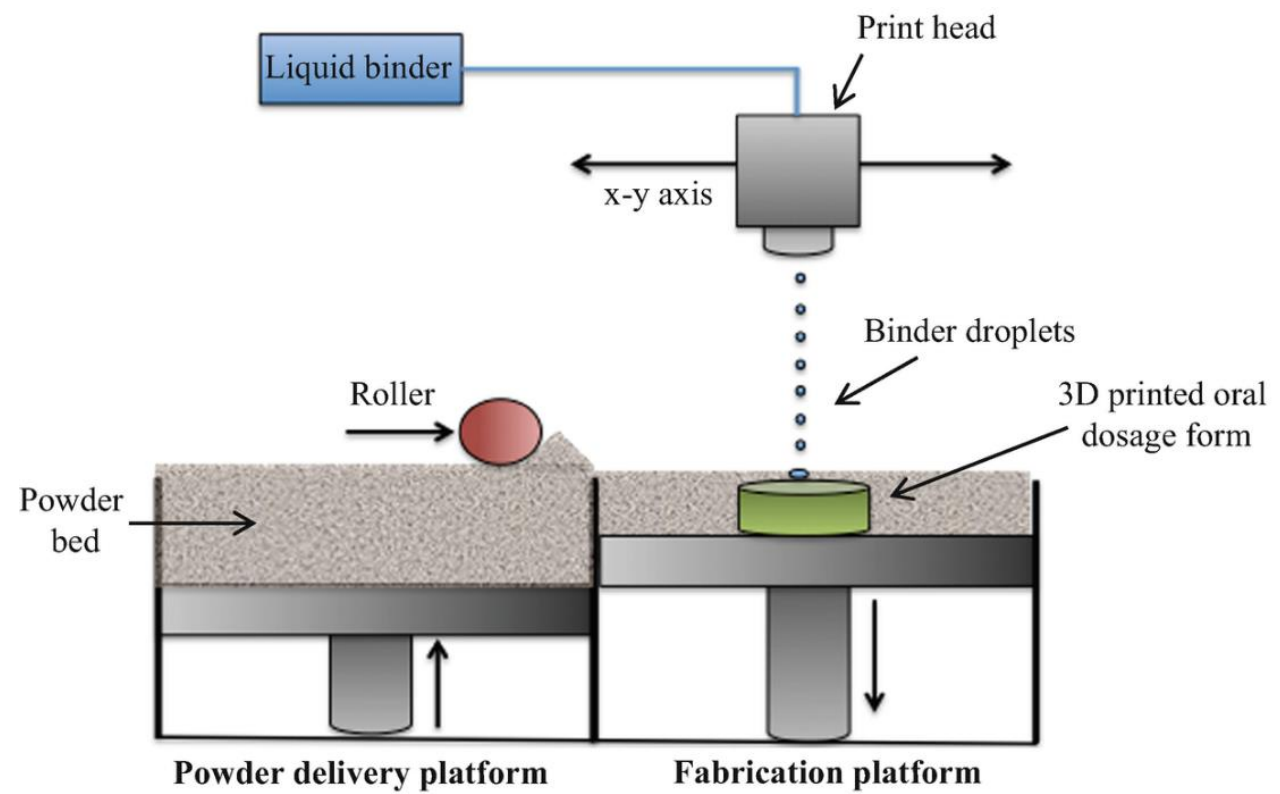

Fig. 3. Working principle of Binder Jetting process [4]

(iv) Material Jetting (MJ)

Material Jetting (MJ) is an AM technique that uses thermoplastics droplets and photopolymers that are selectively deposited with the help of ultraviolet (UV) light [5]. These systems adapt the inkjet-headed and popular polyjet machines [6]. The dispenser drops droplets of the material, which solidifies under UV light [7]. The MJ process produces parts with a high surface finish and high dimensional accuracy. Multi-material printing is also possible using the MJ process [8]. Figure 4 indicates the schematic diagram of the MJ process. 


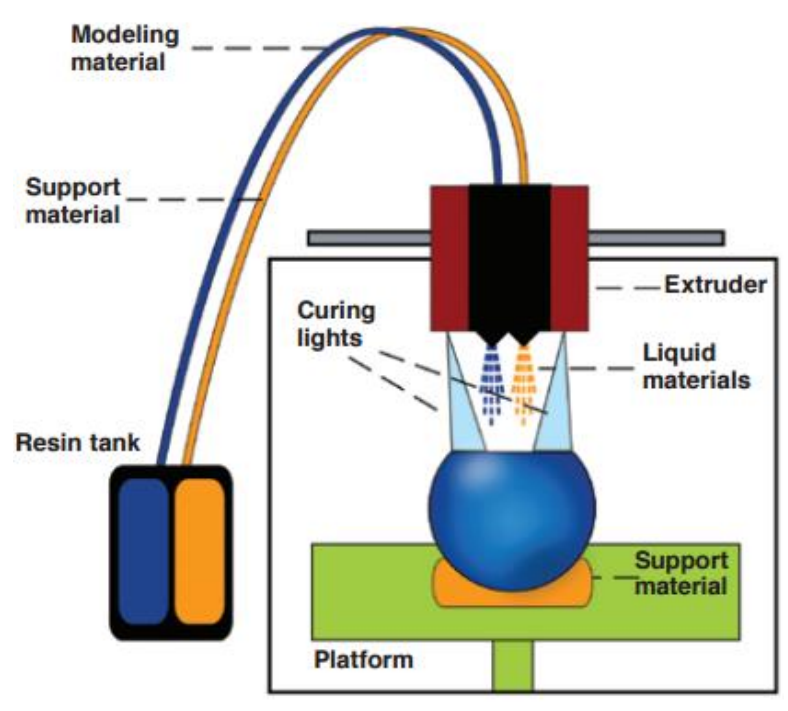

Fig. 4. Schematic diagram of Material Jetting [5]

\section{(v) Sheet Lamination (SL)}

Sheet Lamination (SL) is an AM technique that bonds together sheets to form the final product [7]. Ultrasound Additive Manufacturing (UAM) and Laminated Object Manufacturing (LOM) are the prominent methods of this technique. The LOM process can make full-color prints, recycling the excess material, and the process is relatively inexpensive. LOM process can print complex geometry at less operation time, quicker and inexpensive [9]. Figure 5 shows the schematic diagram of the LOM technique.

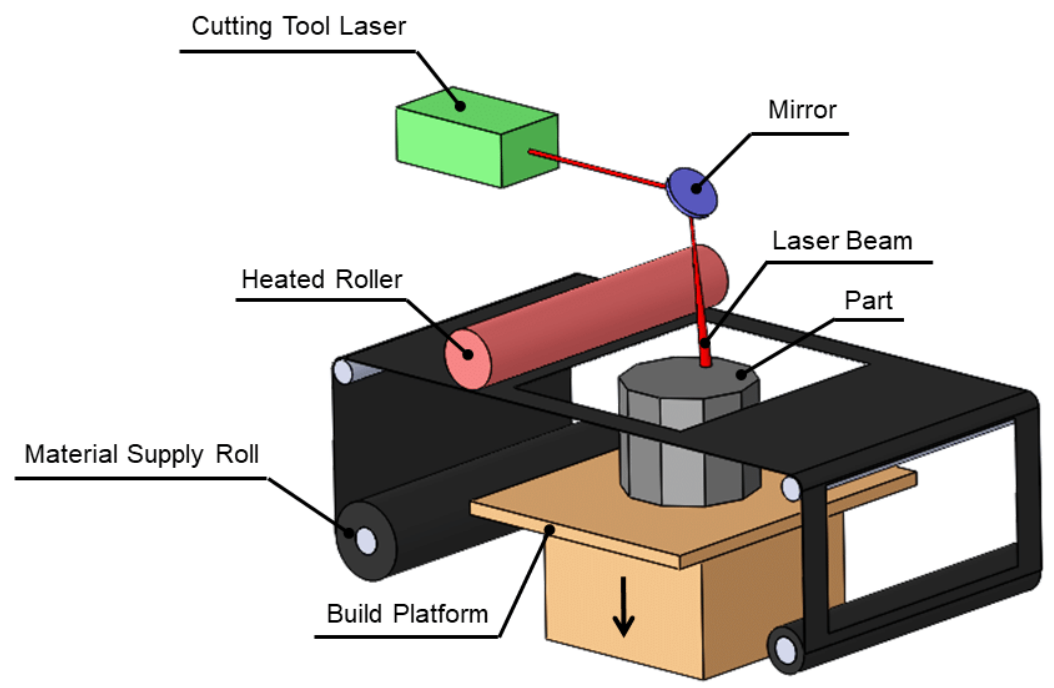

Fig. 5. Laminated Object Manufacturing (LOM) [10]

(vi) VAT Photopolymerization (VP)

VAT Photopolymerization (VP) is an AM process in which photoreactive polymer in a VAT is cured by laser, light, or ultraviolet (UV) polymerization [11]. The prominent examples of this method are Stereolithography (SLA) and Digital Light Processing (DLP) [12]. The photo-initiator and the radiation exposure affect the SLA and DLP process. DLP uses a more convenient source of light, like an arc lamp 
with a fluid crystal panel, and it can be used to cure the entire surface of the photopolymer resin vat in a single pass. Also, this process is faster than the SLA technique [13]. VAT Photopolymerization's essential parameters include the exposure period, wavelength, and power source. Photopolymerization effectively produces parts with a high degree of surface quality and build quality [14]. Figure 6 shows the construction and working of the VAT Photopolymerization process.

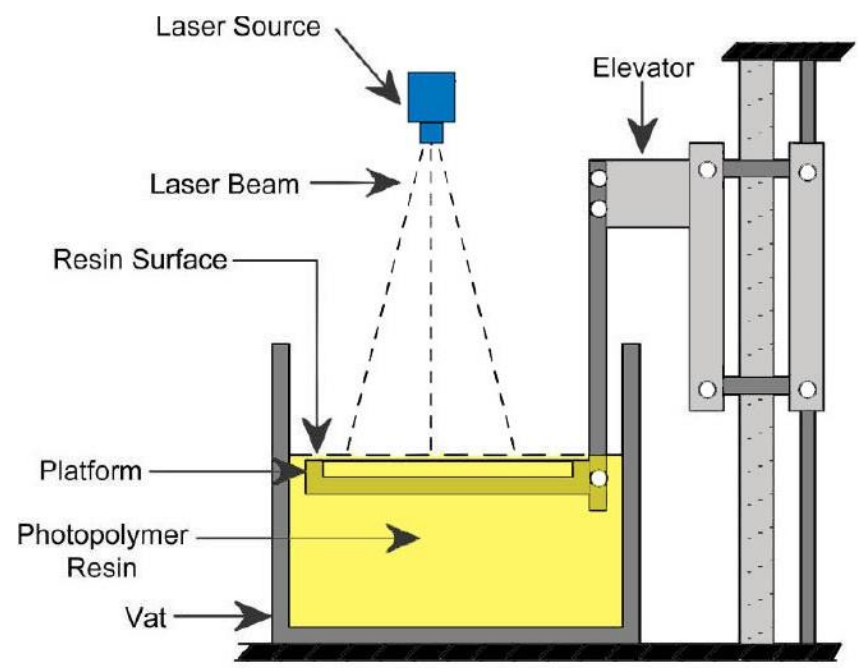

Fig. 6. Vat photopolymerization process [15]

(vii)

Directed Energy Deposition (DED)

Directed Energy Deposition (DED) is a relatively complicated printing method [16]. It has a high degree of grain structure control and can produce good object quality. In theory, the DED method is identical to material extrusion; the key difference is the nozzle which can move in multiple directions and not be fixed to a specific axis. Laser Deposition (LD) and Laser Engineered Net Shaping (LENS) are prominent examples of the DED process. Laser Deposition is the latest technique to produce or repair particles from millimeter to meter. This process can be used with ceramics and polymers but highly preferred for metals and hybrids based on metals of wire or powder [12]. Figure 7 shows the schematic diagram of the LENS process.

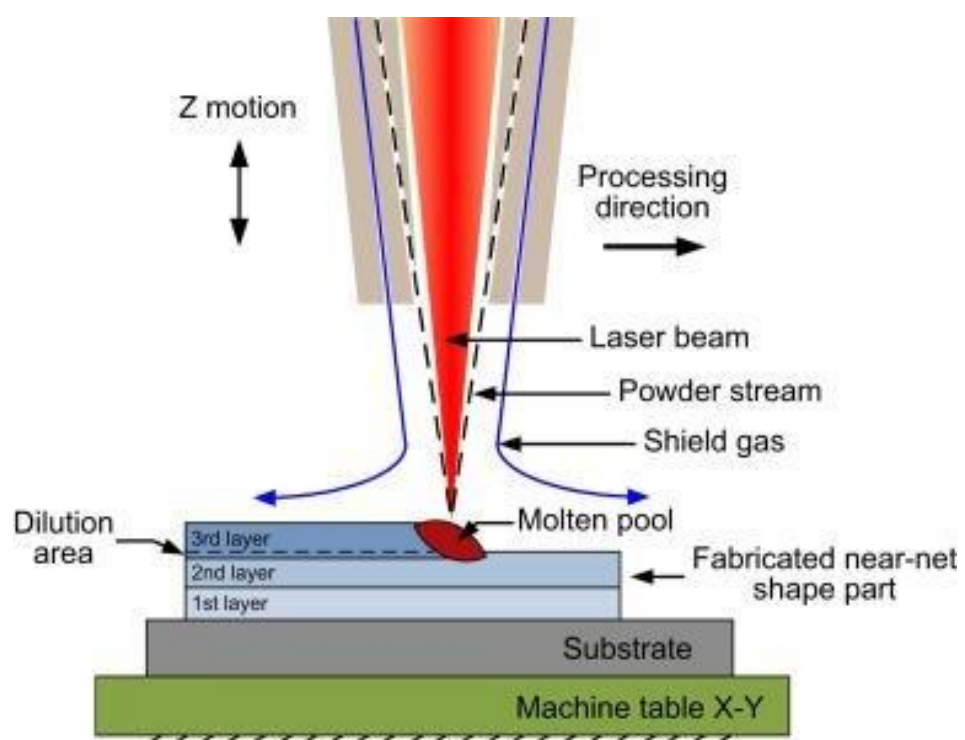

Fig. 7. Laser Engineered Net Shaping (LENS) process [17] 
From the conducted literature studies, every different process reported having its own specification of materials, size, design, and properties. Each approach has merits and demerits by the use of materials, productivity, and cost-effectiveness. The advantages and disadvantages of different AM techniques are shown in Table 1.

Table 1

Advantages and disadvantages of different AM techniques, $[18,19]$

\begin{tabular}{|c|c|c|}
\hline AM Technique & Advantages & Disadvantages \\
\hline Material Extrusion (ME) & $\begin{array}{l}\text { - Low startup cost } \\
\text { - Wide range of raw materials } \\
\text { - Adaptable } \\
\text { - Can build fully functional parts }\end{array}$ & $\begin{array}{l}\text { - Longer built time with lower } \\
\text { precision } \\
\text { - Hard to print sharp angles } \\
\text { - Vertical anisotropy }\end{array}$ \\
\hline Powder Bed Fusion (PBF) & $\begin{array}{l}\text { - No support structure is required for } \\
\text { polymer powder } \\
\text { - Recyclable for both polymer powder and } \\
\text { metal } \\
\text { - Ability to print a variety of materials with } \\
\text { complex geometry } \\
\text { Better resolution and accuracy for metal } \\
\text { powder printed part }\end{array}$ & $\begin{array}{l}\text { - Low printing rate } \\
\text { - Higher startup cost required } \\
\text { (expensive machines) } \\
\text { - Limited built part size } \\
\text { - } \text { Rough surface finish for polymer }\end{array}$ \\
\hline Binder Jetting (BJ) & $\begin{array}{l}\text { - Wide range of raw materials } \\
\text { - Automatically fabricate support structure; } \\
\text { thus, no support structured required }\end{array}$ & $\begin{array}{l}\text { - Printed parts are rough surfaces } \\
\text { and poor strength } \\
\text { - Required post-processing to } \\
\text { improve strength \& remove } \\
\text { moisture }\end{array}$ \\
\hline Material Jetting (MJ) & $\begin{array}{l}\text { - Produce high resolution and accuracy } \\
\text { parts } \\
\text { - Variety of colors and materials are } \\
\text { possible } \\
\text { - No wastage of model material }\end{array}$ & $\begin{array}{l}\text { - Wastage of support materials } \\
\text { (not to be recycled) } \\
\text { - Post-processing is not suggested } \\
\text { for small features to minimizes } \\
\text { damage }\end{array}$ \\
\hline Sheet Lamination (SL) & $\begin{array}{l}\text { Variety of colors and materials are } \\
\text { possible } \\
\text { - Higher printing speed } \\
\text { - Low internal stress and warping and } \\
\text { stress. } \\
\text { - No support structured required }\end{array}$ & $\begin{array}{l}\text { - Removal of support structure } \\
\text { could be difficult. } \\
\text { - Wastage of materials } \\
\text { - The heat of the laser might } \\
\text { cause warpage of lamination }\end{array}$ \\
\hline $\begin{array}{l}\text { Vat Photopolymerization } \\
\text { (VP) }\end{array}$ & $\begin{array}{l}\text { - Produce good surface finish, high } \\
\text { - } \text { resolution, and accuracy parts. } \\
\text { - } \text { Higher printing speed } \\
\text { - } \quad \text { Low-imaging specific energy }\end{array}$ & $\begin{array}{l}\text { - Support structure required. } \\
\text { - Post-processing and post-curing } \\
\text { are required }\end{array}$ \\
\hline $\begin{array}{l}\text { Direct Energy Deposition } \\
\text { (DED) }\end{array}$ & $\begin{array}{l}\text { - } \quad \text { Effective for add-on and repair features } \\
\text { - } \quad \text { Suitable for large metal components } \\
\text { - High material utilization } \\
\text { - High degree control of grain structures }\end{array}$ & $\begin{array}{l}\text { - Printed parts are poor accuracy } \\
\text { and surface finish } \\
\text { - Complex geometry is not } \\
\text { possible } \\
\text { - Many materials are not suitable } \\
\text { for this printing process }\end{array}$ \\
\hline
\end{tabular}

\section{Materials For 3D Printing}

In the 3D printing process, a wide range of materials has been developed and shown successful use with this process. These materials have different mechanical and other properties. Researchers are also continuously developing a new class of materials to be used with the 3D printing process. 
The common materials used in the 3D printing process are polymers, polymer composites, ceramics, metals, and hybrid composites. Table 2 demonstrates the various materials used for the 3D printing process, method of processing, resolution of various processes, and applications.

Table 2

Materials used for various 3D printing processes [20-22]

\begin{tabular}{|c|c|c|c|c|c|}
\hline Method & Materials & Process & Resolution & Build volume $\left(\mathrm{mm}^{3}\right)$ & Applications \\
\hline $\mathrm{ME}$ & $\begin{array}{l}\text { - Polymers } \\
\text { - Ceramics } \\
\text { - Composites }\end{array}$ & $\begin{array}{l}\text { Material is } \\
\text { continuously } \\
\text { pushed through } \\
\text { the nozzle in the } \\
\text { filament form }\end{array}$ & $50-200 \mu \mathrm{m}$ & $900 \times 600 \times 900$ & $\begin{array}{l}\text { Aerospace parts, } \\
\text { Prototypes, Jigs \& } \\
\text { fixtures, Supporting } \\
\text { parts, food } \\
\text { applications, }\end{array}$ \\
\hline PBF & $\begin{array}{l}\text { - Polymers } \\
\text { - Ceramics } \\
\text { - Composites } \\
\text { - Metals } \\
\text { - Hybrid }\end{array}$ & $\begin{array}{l}\text { The build } \\
\text { materials are } \\
\text { fused by the } \\
\text { thermal energy }\end{array}$ & $80-250 \mu \mathrm{m}$ & $300 \times 300 \times 350$ & $\begin{array}{l}\text { Prototypes, Small } \\
\text { series types, } \\
\text { Supporting parts }\end{array}$ \\
\hline BJ & $\begin{array}{l}\text { - Polymers } \\
\text { - Ceramics } \\
\text { - Composites } \\
\text { - Metals } \\
\text { - Hybrid }\end{array}$ & $\begin{array}{l}\text { The component is } \\
\text { formed layer } \\
\text { after layer as the } \\
\text { particles are } \\
\text { bonded together }\end{array}$ & $5-200 \mu \mathrm{m}$ & $4000 \times 2000 \times 1000$ & $\begin{array}{l}\text { Prototypes, Green } \\
\text { parts, Casting } \\
\text { patterns, Moulds, } \\
\text { and cores }\end{array}$ \\
\hline MJ & $\begin{array}{l}\text { - Polymers } \\
\text { - Ceramics } \\
\text { - Composites } \\
\text { - Hybrid } \\
\text { - biologicals }\end{array}$ & $\begin{array}{l}\text { Deposited } \\
\text { droplets of } \\
\text { building materials }\end{array}$ & $5-200 \mu \mathrm{m}$ & $300 \times 200 \times 200$ & $\begin{array}{l}\text { Prototypes, casting } \\
\text { patterns }\end{array}$ \\
\hline SL & $\begin{array}{l}\text { - Polymers } \\
\text { - Ceramics } \\
\text { - Papers } \\
\text { - Metals } \\
\text { - Hybrid }\end{array}$ & $\begin{array}{l}\text { Sheets of raw } \\
\text { materials are } \\
\text { bonded }\end{array}$ & $\begin{array}{l}\text { The } \\
\text { resolutions } \\
\text { vary } \\
\text { depending } \\
\text { on the } \\
\text { thickness of } \\
\text { the sheets }\end{array}$ & $250 \times 200 \times 150$ & $\begin{array}{l}\text { Less detailed parts, } \\
\text { rapid tooling patterns }\end{array}$ \\
\hline VP & $\begin{array}{l}\text { - } \text { Polymers } \\
\text { - } \text { Ceramics, } \\
\text { - } \text { resins with } \\
\text { photo-active } \\
\text { monomers }\end{array}$ & $\begin{array}{l}\text { The liquid } \\
\text { polymers in a VAT } \\
\text { were cured by } \\
\text { light }\end{array}$ & $10 \mu \mathrm{m}$ & $2100 \times 700 \times 800$ & $\begin{array}{l}\text { Rapid tooling } \\
\text { patterns, Snap fits, } \\
\text { Presentation models, } \\
\text { High heat } \\
\text { applications }\end{array}$ \\
\hline DED & $\begin{array}{l}\text { - Metals } \\
\text { - Hybrid }\end{array}$ & $\begin{array}{l}\text { Thermal energy } \\
\text { concentrates on } \\
\text { melting materials } \\
\text { during deposition }\end{array}$ & $250 \mu \mathrm{m}$ & $3000 \times 3500 \times 5000$ & $\begin{array}{l}\text { Rapid tooling, High } \\
\text { heat applications, } \\
\text { Medical implants, } \\
\text { Aerospace parts }\end{array}$ \\
\hline
\end{tabular}

\subsection{Material Properties and Applications}

The material selection for the 3D printing process varies depending on the application and the expected quality of the product. The leading process of this 3D printing is Fused Deposition Modeling (FDM), Stereolithography (SLA), Selective Laser Sintering (SLS), Direct Metal Laser Sintering (DMLS). The various materials used in these processes, their properties, and the applications are shown in Table 3. 
Table 3

Materials, benefits, and applications of major processes of 3D printing technique [23]

\begin{tabular}{|c|c|c|c|}
\hline Process & Material & Properties & Applications \\
\hline FDM & $\begin{array}{ll}\text { - } & \text { ABS } \\
\text { - } & \text { PLA } \\
\text { - } & \text { PC } \\
\text { - } & \text { NYLON } \\
\text { - } & \text { PC-ABS } \\
\text { - } & \text { ULTEM }\end{array}$ & $\begin{array}{l}\text { - } \quad \text { strong and tough } \\
\text { and tensile strength } \\
\text { - High tensile and flexural } \\
\text { strength } \\
\text { - High impact and fatigue } \\
\text { resistance and good } \\
\text { chemical resistance } \\
\text { - High impact and heat } \\
\text { resistance } \\
\text { - High thermal and } \\
\text { chemical strength, } \\
\text { biocompatible, high } \\
\text { strength to weight ratio }\end{array}$ & $\begin{array}{l}\text { - } \begin{array}{l}\text { Aerospace, automobile, medical, end-user } \\
\text { - }\end{array} \text { Parts } \\
\text { envinted parts for homentally friendly and required } \\
\text { aesthetic details } \\
\text { - } \quad \text { Aerospace and automobile industries, } \\
\text { functional prototypes } \\
\text { - Prototypes for electrical housings, } \\
\text { automotive parts, brackets, and parts for } \\
\text { outdoor use } \\
\text { - Low volume production parts, industrial } \\
\text { - } \text { equipment, functional prototypes } \\
\text { applications, ECS ducting, metal forming } \\
\text { tools, aircraft interior replacement tools }\end{array}$ \\
\hline SLA & $\begin{array}{ll}\text { - } & \text { Somos }^{\circledR} \text { NeXt } \\
\text { - } & \text { SC } 1000 \mathrm{P} \\
\text { - } & \text { Somos } \\
& \text { ProtoGen } \\
& 18420 \\
\text { - } & \text { Somos } \\
& \text { Ultra } 10122\end{array}$ & $\begin{array}{l}\text { - High impact strength and } \\
\text { durability, Enormously } \\
\text { versatile } \\
\text { - Low cost, high accuracy } \\
\text { - High accuracy and } \\
\text { functional properties } \\
\text { - Colorless, easy to finish }\end{array}$ & $\begin{array}{l}\text { - Tough, functional end-use prototypes, jigs } \\
\text { \& fixtures, food packaging, and sporting } \\
\text { goods } \\
\text { - } \text { Investment casting, lightweight models } \\
\text { - } \text { Automotive parts, consumer, and } \\
\text { electrical products } \\
\text { - Automotive lenses, bottles, light pipes }\end{array}$ \\
\hline SLS & $\begin{array}{ll}\text { - } & \text { Flex TPE } \\
\text { - } & \text { Nylon } 12 \mathrm{PA} \\
\text { - } & \text { Nylon } 12 \mathrm{GF}\end{array}$ & $\begin{array}{l}\text { - Rapid operating } \\
\text { prototypes with } \\
\text { elastomeric properties } \\
\text { - Good chemical } \\
\text { resistance and surface } \\
\text { resolution, low moisture } \\
\text { absorption, } \\
\text { - Good mechanical } \\
\text { stiffness, elevated } \\
\text { temperature resistance, } \\
\text { dimensionally stability }\end{array}$ & $\begin{array}{l}\text { - Compression seals, protective boots, and } \\
\text { shields } \\
\text { - Impellers, connectors, complex plastic } \\
\text { parts, end-use parts } \\
\text { - Housing and enclosures, consumer } \\
\text { sporting goods, functional prototypes }\end{array}$ \\
\hline DMLS & $\begin{array}{l}\text { - Stainless steel } \\
\text { - } \text { Aluminum } \\
\text { - Nickel alloy } \\
\text { - } \text { Titanium }\end{array}$ & $\begin{array}{l}\text { Good strength and } \\
\text { creep resistance, } \\
\text { excellent weldability, } \\
\text { and corrosion } \\
\text { resistance, cost- } \\
\text { effective } \\
\text { - Low weight, good } \\
\text { thermal properties, } \\
\text { hardness, and strength. } \\
\text { Superb machinability } \\
\text { High corrosion } \\
\text { resistance, nigh creep, } \\
\text { tensile and rupture } \\
\text { strengths } \\
\text { Good mechanical } \\
\text { properties, good wear, } \\
\text { and carrion resistance }\end{array}$ & $\begin{array}{l}\text { - Aerospace, automotive, and oil \& gas } \\
\text { industries. Parts requiring high strength } \\
\text { and corrosion resistance } \\
\text { - Aerospace, automobile. Complex } \\
\text { geometries and low-cost prototypes } \\
\text { - Turbine engine components, petroleum } \\
\text { industries } \\
\text { - Aerospace structures and engine } \\
\text { components, biomedical implants }\end{array}$ \\
\hline
\end{tabular}




\section{Parameters of 3D Printing}

Process parameter is an important element in the 3D printing process. As to date, several parameters of 3D printing have already been studied for optimum mechanical properties, surface finish, and printing time. Layer thickness, build orientation, raster angle, printing temperature, air gap, and infill pattern has been reported to be the primary parameters that affect the properties of the 3D printed parts. Optimizing these parameters would lead to better properties. Table 4 shows the process parameter optimization of various methods.

- Layer thickness: Is the thickness of the building part for every layer. The less the thickness of the layer, the better accuracy of the part.

- Raster angle: Is the direction of the raster with respect to the loading direction.

- Build orientation: It is known as the orientation of the part over the build plate on the $X, Y$, and Z-axis.

- Printing temperature: The temperature is classified into two types. (i) Nozzle temperature: It is the temperature of the extrusion nozzle (ii) Bed temperature: It is the temperature of the bed (build plate).

- Air gap: The gap between two rasters is called an air gap.

- Infill pattern: Is the structure or shape of the material inside the part.

- Infill density: Is the amount of material used inside the printed part.

- Raster width: The raster width or road width implies the width of the deposition path related to tip size.

The 3D printing parameters have been investigated by numerous researchers using various types of experimental investigations. The experimental is necessary to understand the effect of printing parameters and optimization required for better materials behavior. From Table 4, it can be seen that quite a number of parameters have been analyzed, and the output of the properties varies depending on the parameters. The present review findings show that the minimum layer thickness has superior mechanical properties and surface finish than the thicker layers. Also, minimizing the layer thickness reduces the air gap, which improves the bonding of the layers and increases the product's strength. The printing speed is also seen to be a critical factor to increase the quality of the product. Slower printing speed ensures the filament extruded from the nozzle is continuous and without breaking. The slower printing speed also produces better surface finish and mechanical properties than the higher printing speed. The nozzle temperatures are suggested to be high during printing for a better mechanical property. The high temperature provides a good bonding between the layers resulting in better properties. Raster angle, infill pattern, and the build orientation are also the critical parameters for optimum properties of the product. The present review has also identified that the flat orientation and $0^{\circ}$ raster angle produces a good quality product. 


\section{Table 4}

Process parameter optimization of various methods

\begin{tabular}{l}
\hline Parameters \\
\hline Printing orientation - \\
vertical and horizontal \\
Layer thickness - 0.1, 0.2, \\
$0.3,0.4(\mathrm{~mm})$ \\
Nozzle temperature - \\
$400,410,420,430,440$ \\
$\left({ }^{\circ} \mathrm{C}\right)$
\end{tabular}

$\left({ }^{\circ} \mathrm{C}\right)$

Platform temperature $240,250,260,270,280$

$\left({ }^{\circ} \mathrm{C}\right)$

Printing speed $-5,10,15$, $20,25(\mathrm{~mm} / \mathrm{s})$

Layer thickness - 0.1, $0.15,0.2,0.25(\mathrm{~mm})$ Extruding rate -27.3 , 29.2, 32.3, 35.4, 39.7, $44.1,50.2,52.4,54.7$, $60.5(\mathrm{~mm} 3 / \mathrm{s})$

Printing speed - 18.3, 20.6, 22.4, 25.7, 37.9 (mm/s)

Printing speed $-50,52$, $54,56,58,60(\mathrm{~mm} / \mathrm{s})$

Volume flowrate - 37.9, $45.2,48.0,51.3(\mathrm{ml} / \mathrm{s})$

Printing speed - 200, 180,160, 140, 120, 100, $80,60(\mathrm{~mm} / \mathrm{s})$

Deposition rate $-1,88$, $175\left(\mathrm{~mm}^{3} / \mathrm{s}\right)$

Deposition temperature -

- Young's modulus

- Tensile strength

- Elongation $153,173,190\left({ }^{\circ} \mathrm{C}\right)$

Layer thickness - 0.1, 0.2, $0.3(\mathrm{~mm})$

Printing speed $-25,50$

(mm/min)

Layer thickness - 0.1, 0.2 (mm) conductive material

- Electron transfer kinetics

- Impact strength

- Flexural strength

- Tensile strength

- Food paste properties

- Deformation of printed 3D cementitious material

- Effect of printing parameters optimization

- Mechanical properties of

Properties Results
parameters in 3D concrete printing

- Stereolithography flexural strength and hardness
Electrodes printed with a layer thickness of 0.1 $\mathrm{mm}$ in a vertical orientation achieved the highest

Large filament surface area was found in high flow rate and slow printing speed. It is given better mechanical strength, but poor geometrical resolution and surface finish. Low flow rates and fast printing speed gives large breaks. This break was caused by the disproportionate slow flow rate of the material exiting the nozzle.

Increases in layer thickness led to lower mechanical properties. Temperature increases tended to increase in both mechanical properties. Increases in deposition rate were increasing the mechanical properties.

Ref
Abdalla et
al., [24]

horizontally oriented printing resulted in more resistive electrodes.

ozzle temperature: tensile and flexural strength

Wang et

al., [25] that the strength increases slowly and drops at 410 as temperature increases. Printing speed: Increasing the speed of printing has decreased strength. decreased the strength.

The most suitable printing speed and the extruding rate is $22.4 \mathrm{~mm} / \mathrm{s}$ and $39.7 \mathrm{~mm}^{3} / \mathrm{s}$. The most not

Liu and Ciftci [26]

The deformation of the printed filament increases

Liu et al., [27]

Tay et al., [28]

Carlier et al., [29]

For flexural strength, layer height0.1 $\mathrm{mm}$ is higher than the $0.2 \mathrm{~mm}$, and for up speed, the slower $25 \mathrm{~mm} / \mathrm{min}$ also has higher flexural strength than $50 \mathrm{~mm} / \mathrm{min}$. For hardness, $0.2 \mathrm{~mm}$ layer height has a better result than the $0.1 \mathrm{~mm}$, while the upspeed result is $25 \mathrm{~mm} / \mathrm{min}$ is higher than $50 \mathrm{~mm} / \mathrm{min}$.
Munprom and Limtasiri [30] 


\section{Future Perspective}

3D printing has benefits such as the ability to print complicated structures and relatively quicker than the conventional methodologies. The productivity of this technology has also been proven effective in various sectors such as aerospace, automobile, electronics, medical, food packaging, construction, and home appliances. However, to further cater to the demand for specific and customized parts, 3D printing technology is enthused to another level known as 4D printing. 4D printing uses shape memory polymers for more specific applications.

Also, several disadvantages need serious attention for better technological development. The drawbacks are anisotropic mechanical properties, limited applications due to limited materials, and high-cost limited applications in large structures. Material and methodology study and development have helped to avoid some of these difficulties. But few problems remain to be tackled to extend additive manufacturing (AM) to a broader variety of applications and industries. The 3D printing process takes more time to produce the part compared with conventional machining and injection molding processes. Compared with FDM and Inkjet printing process, the PBF and SLA processes are more time-consuming. The time consumption and the cost will restrict the mass usage of the 3D printing process.

The void formation between the consequent layers is also a significant challenge in this 3D printing process. The porosity created between the layers will reduce the mechanical strength of the product. Anisotropic mechanical properties even the major problem in the AM process. The microstructure of the inner layers is different compared with the outer layers. The insufficient parameters of the process are the main reason for these problems. As such, the future perspective should be mainly focused on optimizing the parameters of the AM process.

\section{Conclusions}

Over the last few years, 3D printing technology has emerged as a versatile and efficient technique for advanced manufacturing. This technology has been widely used in many sectors, particularly in the manufacturing sector. Liberty in design, the ability to print complex structures, and minimize wastage are the important benefits of the 3D printing process. This review contains various techniques in the 3D printing process. The various materials used and the properties and the applications in various sectors and parameters to optimize the better mechanical properties were discussed. From the studies compared with the Selective Laser Melting (SLM) and Selective Laser Sintering (SLS) process, the mechanical properties of the Fused Deposition Modeling (FDM) are comparatively low. Still, this process is cost-efficient, easy to use, and high-speed processing. Layer thickness, raster angle, and build orientation are the crucial parameters in the 3D printing process. Optimizing the processing parameters will be helpful for optimum utilization in various sectors such as aerospace, medical, electronics, and others.

\section{Acknowledgment}

The authors are grateful to Universiti Malaysia Pahang (www.ump.edu.my) for the financial support provided under the grant PGRS 190339, RDU192216, and RDU192401. 


\section{References}

[1] Tofail, Syed A. M., Elias P. Koumoulos, Amit Bandyopadhyay, Susmita Bose, Lisa O'Donoghue, and Costas Charitidis. "Additive manufacturing: scientific and technological challenges, market uptake and opportunities." Materials Today 21, no. 1 (2018): 22-37. https://doi.org/10.1016/j.mattod.2017.07.001

[2] Reddy, Bathula Sreenivas. "3D Printing for Foot." MOJ Proteomics \& Bioinformatics 5, no. 6 (2017): 00176. https://doi.org/10.15406/mojpb.2017.05.00176

[3] Aichner, Thomas. "Mass Customization: Do Creative Product Configurations in Ads Drive Behavioural Intention and Perceived Product Quality?" Proceedings of the 8th International Conference on Mass Customization and Personalization - Community of Europe (MCP-CE 2018) (2018).

[4] Trenfield, Sarah J., Christine M. Madla, Abdul W. Basit, and Simon Gaisford. "Binder jet printing in pharmaceutical manufacturing." In 3D Printing of Pharmaceuticals, pp. 41-54. Springer, Cham, 2018. https://doi.org/10.1007/9783-319-90755-0 3

[5] Silbernagel, Cassidy. "Additive Manufacturing 101-4: What is material jetting?" Canada Makes, April 26, 2018. http://canadamakes.ca/what-is-material-jetting/.

[6] Li, Pengfei, Yadong Gong, Yunchao Xu, Yang Qi, Yao Sun, and Huan Zhang. "Inconel-steel functionally bimetal materials by hybrid directed energy deposition and thermal milling: Microstructure and mechanical properties." Archives of Civil and Mechanical Engineering 19 (2019): 820-831. https://doi.org/10.1016/i.acme.2019.03.002

[7] Dilag, Jessirie, Tiffany Chen, Sheng Li, and Stuart A. Bateman. "Design and direct additive manufacturing of threedimensional surface micro-structures using material jetting technologies." Additive Manufacturing 27 (2019): 167174. https://doi.org/10.1016/i.addma.2019.01.009

[8] Tofail, Syed AM, Elias P. Koumoulos, Amit Bandyopadhyay, Susmita Bose, Lisa O'Donoghue, and Costas Charitidis. "Additive manufacturing: scientific and technological challenges, market uptake and opportunities." Materials Today 21, no. 1 (2018): 22-37. https://doi.org/10.1016/i.mattod.2017.07.001

[9] Vijayavenkataraman, Sanjairaj, Jerry YH Fuh, and Wen Feng Lu. "3D printing and 3D bioprinting in pediatrics." Bioengineering 4, no. 3 (2017): 63. https://doi.org/10.3390/bioengineering 4030063

[10] Razavykia, Abbas, Eugenio Brusa, Cristiana Delprete, and Reza Yavari. "An Overview of Additive Manufacturing Technologies-A Review to Technical Synthesis in Numerical Study of Selective Laser Melting." Materials 13, no. 17 (2020): 3895. https://doi.org/10.3390/ma13173895

[11] Aduba Jr, Donald C., Evan D. Margaretta, Alexandra EC Marnot, Katherine V. Heifferon, Wyatt R. Surbey, Nicholas A. Chartrain, Abby R. Whittington, Timothy E. Long, and Christopher B. Williams. "Vat photopolymerization 3D printing of acid-cleavable PEG-methacrylate networks for biomaterial applications." Materials Today Communications 19 (2019): 204-211. https://doi.org/10.1016/i.mtcomm.2019.01.003

[12] Shahrubudin, Nurhalida, Te Chuan Lee, and Rhaizan Ramlan. "An overview on 3D printing technology: Technological, materials, and applications." Procedia Manufacturing 35 (2019): 1286-1296. https://doi.org/10.1016/i.promfg.2019.06.089

[13] Chartrain, Nicholas A., Christopher B. Williams, and Abby R. Whittington. "A review on fabricating tissue scaffolds $\begin{array}{llllll} & \text { using vat }\end{array}$ https://doi.org/10.1016/i.actbio.2018.05.010

[14] Frketic, Jolie, Tarik Dickens, and Subramanian Ramakrishnan. "Automated manufacturing and processing of fiberreinforced polymer (FRP) composites: An additive review of contemporary and modern techniques for advanced materials manufacturing." Additive Manufacturing 14 (2017): 69-86. https://doi.org/10.1016/i.addma.2017.01.003

[15] Nikhil, A. "3D Printing Processes - Vat Photo polymerisation (Part 3/8)." Engineers Garage, January 10, 2017. https://www.engineersgarage.com/tech-articles/3d-printing-processes-vat-photo-polymerisation-part-3-8/.

[16] Tofail, Syed A. M., Elias P. Koumoulos, Amit Bandyopadhyay, Susmita Bose, Lisa O'Donoghue, and Costas Charitidis. "Additive manufacturing: scientific and technological challenges, market uptake and opportunities." Materials Today 21, no. 1 (2018): 22-37. https://doi.org/10.1016/i.mattod.2017.07.001

[17] Dehghanghadikolaei, Amir, Navid Namdari, Behrouz Mohammadian, and B. J. J. O. S. Fotovvati. "Additive manufacturing methods: a brief overview." Journal of Scientific and Engineering Research 5 (2018): 123-131.

[18] Diegel, Olaf, Axel Nordin, and Damien Motte. "Additive manufacturing technologies." In A Practical Guide to Design for Additive Manufacturing, pp. 19-39. Springer, Singapore, 2019. https://doi.org/10.1007/978-981-13-8281-9 2

[19] Lee, Jian-Yuan, Jia An, and Chee Kai Chua. "Fundamentals and applications of 3D printing for novel materials." Applied Materials Today 7 (2017): 120-133. https://doi.org/10.1016/i.apmt.2017.02.004

[20] Ramya, A., and Sai Leela Vanapalli. "3D printing technologies in various applications." International Journal of Mechanical Engineering and Technology 7, no. 3 (2016): 396-409.

[21] Additively. "Overview over 3D printing technologies." Additively.com, Accessed January 29, 2021. https://www.additively.com/en/learn-about/3d-printing-technologies. 
[22] Ngo, Tuan D., Alireza Kashani, Gabriele Imbalzano, Kate T. Q. Nguyen, and David Hui. "Additive manufacturing (3D printing): A review of materials, methods, applications and challenges." Composites Part B: Engineering 143 (2018): 172-196. https://doi.org/10.1016/j.compositesb.2018.02.012

[23] Stratasys. "Aerospace - Parts On Demand." Stratasys Direct Manufacturing, Accessed January $29,2021$. https://www.stratasysdirect.com/.

[24] Abdalla, A., H. H. Hamzah, O. Keattch, D. Covill, and B. A. Patel. "Augmentation of conductive pathways in carbon black/PLA 3D-printed electrodes achieved through varying printing parameters." Electrochimica Acta 354 (2020): 136618. https://doi.org/10.1016/i.electacta.2020.136618

[25] Wang, Peng, Bin Zou, Shouling Ding, Lei Li, and Huang Chuanzhen. "Effects of FDM-3D printing parameters on mechanical properties and microstructure of CF/PEEK and GF/PEEK." Chinese Journal of Aeronautics (2020). https://doi.org/10.1016/i.cja.2020.05.040

[26] Liu, Lingyi, and Ozan N. Ciftci. "Effects of high oil compositions and printing parameters on food paste properties and printability in a 3D printing food processing model." Journal of Food Engineering 288 (2021): 110135. https://doi.org/10.1016/i.jfoodeng.2020.110135

[27] Liu, Zhixin, Mingyang Li, Yiwei Weng, Ye Qian, Teck Neng Wong, and Ming Jen Tan. "Modelling and parameter optimization for filament deformation in 3D cementitious material printing using support vector machine." Composites Part B: Engineering 193 (2020): 108018. https://doi.org/10.1016/i.compositesb.2020.108018

[28] Tay, Yi Wei Daniel, Ming Yang Li, and Ming Jen Tan. "Effect of printing parameters in 3D concrete printing: printing region and support structures." Journal of Materials Processing Technology 271 (2019): 261-270. https://doi.org/10.1016/j.jmatprotec.2019.04.007

[29] Carlier, E., S. Marquette, C. Peerboom, L. Denis, S. Benali, J. M. Raquez, K. Amighi, and J. Goole. "Investigation of the parameters used in fused deposition modeling of poly (lactic acid) to optimize 3D printing sessions." International Journal of Pharmaceutics 565 (2019): 367-377. https://doi.org/10.1016/i.ijpharm.2019.05.008

[30] Munprom, Ratiporn, and Sorawit Limtasiri. "Optimization of stereolithographic 3D printing parameters using Taguchi method for improvement in mechanical properties." Materials Today: Proceedings 17 (2019): 1768-1773. https://doi.org/10.1016/i.matpr.2019.06.209 